\title{
Induction, Growth Kinetics and Morpho-histological Characterization of Neem Callus
}

\author{
Leila Albuquerque Resende de Oliveira ${ }^{1}$, Annie Carolina Araújo de Oliveira ${ }^{1}$, Caroline de Araújo Machado ${ }^{1}$, \\ Milena Nascimento Cardoso ${ }^{1}$, Fernanda Vieira Santana ${ }^{1}$, Isabella Cícera Dias Miranda ${ }^{2}$, \\ Evaristo Mauro de Castro ${ }^{3}$, Ana Veruska Cruz da Silva ${ }^{3} \&$ Ana da Silva Ledo ${ }^{4}$ \\ ${ }^{1}$ Programa de Pós-Graduação em Agricultura e Biodiversidade, Universidade Federal de Sergipe, São Cristóvão, \\ Sergipe, Brazil \\ ${ }^{2}$ Programa de Pós-Graduação em Biotecnologia Industrial, Universidade Tiradentes, Aracaju, Sergipe, Brazil \\ ${ }^{3}$ Universidade Federal de Lavras, Lavras, Minas Gerais, Brazil \\ ${ }^{4}$ Embrapa Tabuleiros Costeiros, Aracaju, Sergipe, Brazil \\ Correspondence: Leila Albuquerque Resende de Oliveira, Programa de Pós-Graduação em Agricultura e \\ Biodiversidade, Universidade Federal de Sergipe, Av. Marechal Rondon s/n, São Cristóvão, Sergipe, Brazil. \\ E-mail: leila.a.resende@gmail.com
}

Received: February 22, 2018

Accepted: April 17, $2018 \quad$ Online Published: May 15, 2018

doi:10.5539/jas.v10n6p283

URL: https://doi.org/10.5539/jas.v10n6p283

\begin{abstract}
Azadirachta indica A. Juss, popularly known as neem, is a species native to India, belonging to family Meliaceae, considered the most important plant species with insecticidal action. The aim of this study was to evaluate the influence of growth regulators on induction and growth of neem callus and to observe their viability for embryogenesis through morpho-histological characteristics. In vitro germinated plants were used for excision of nodal explants. These segments were inoculated in Murashige and Skoog culture medium containing $1.0 \mathrm{mg} / 1$ 2,4-D (2,4-dichlorophenoxyacetic) combined with BAP (6-benzylaminopurine) at the following concentrations: $0.0,0.5,1.0$ and $2.0 \mathrm{mg} / 1$ (T1, T2, T3 and T4 respectively), for callus induction. At 0 (mass of nodal segments without callus), 20, 40 and 60 days of culture, the percentage of callus formation was observed and the callus weight was measured for each treatment and at the end of the 60 days, consistency, color, and cell histology were evaluated. There was callus formation in all treatments tested. The highest induction of Azadirachta indica A. Juss callus is observed in the presence of $1.0 \mathrm{mg} / 1$ 2,4-D $+2.0 \mathrm{mg} / \mathrm{l} \mathrm{BAP}$, with callus showing light brown color, friable consistency and rounded cells with intense cell division, typical of cells with potential embryogenic capacity.
\end{abstract}

Keywords: Azadirachta indica A. Juss, callogenesis, scanning electron microscopy, optical microscopy

\section{Introduction}

Azadirachta indica A. Juss, popularly known as neem, is a fast-growing species, native to India, belonging to the family Meliaceae, characterized by several trees distinguished by wood of great utility (Martinez, 2008).

Historically, neem has been one of the most studied plants and considered important specie with insecticidal action. In its chemical constitution presents a great amount of compounds, limonoids specially, with a range of biological activities. Of these components, the most active, and found in larger amounts in seeds is azadirachtin, which has attracted more attention because it presents isolated effects more selective for insects than the neem extract with all compounds together (Bleicher et al., 2007; Neves et al., 2003). The active substances present in neem also have fungicidal, bactericidal, nematicidal, medicinal (Barrek et al., 2004) and antioxidant properties (Nahak \& Sahu, 2011), as well as antiulcer (Mohapatra et al., 2012) and antidiabetic activities (Patil et al., 2013).

However, the limited geographical distribution (Singh \& Chaturvedi, 2013) of the plant, variability in seed production and recalcitrance (Sidhu et al., 2003), and the possibility of pulp fermentation (Venkateswarlu \& Mukhopadhyay, 1999) are factors that interfere with the accessibility and production of active principles. Biotechnology, through the technique of cell culture and plant organs, offers strategies for the production of plants, and consequently of bioactive molecules, free of influence from external factors, that is, under strictly controlled conditions throughout the year, responding to commercial demand (Singh \& Chaturvedi, 2013). 
Through the in vitro production system, uniform matrices free of pathogens can be obtained on a large scale, in a small physical space and in a short period of time, in an economically viable way (Oliveira et al., 2015). In species of economic interest such as neem, in vitro callus cultivation by somatic embryogenesis has been a valuable strategy for the production of seedlings, in addition to being widely used to produce active principles (Akula et al., 2003; Rodrigues et al., 2009).

Growth regulators, explant type and culture medium conditions are among the many factors that interfere with in vitro culture under controlled conditions (Elhiti \& Stasolla, 2011). The hormonal balance obtained between cytokinins and auxins levels may stimulate cell proliferation. However, Ozias-Akins and Vasil (1985) report that exogenous cytokinins are not always necessary and that many tissues develop in in vitro conditions only with auxin (Nogueira et al., 2007).

In the case of Azadirachta indica, in vitro morphogenesis has already been observed from leaf and radicular explants (Salvi et al., 2001), as well as cotyledonary (Rodrigues et al., 2009), embryonic (Singh \& Chaturvedi, 2013) culture supplemented with various combinations of growth regulators; however, callus induction associated with anatomical studies are still scarce for the specie.

Analyses of the anatomical characteristics in optical microscopy and scanning electron microscopy have been applied in several studies of somatic embryogenesis to provide greater details of the morphology of embryogenic tissues and to identify characteristics of non-viable cells (Nogueira et al., 2007). These studies may also aid in the identification of factors that trigger physiological changes in explants, such as the acquisition of friability or the development of somatic embryos. Therefore, the aim of this study was to evaluate the influence of growth regulators on the induction and growth of neem callus and to observe its viability for embryogenesis through morpho-histological characteristics.

\section{Material and Methods}

Experiments were conducted at the Laboratory of Plant Tissue Culture of Embrapa Coastal Tablelands, Aracaju-SE, Brazil and at the Laboratory of Plant Anatomy and Electron Microscopy and Laboratory of Ultra structural Analysis of the Federal University of Lavras, Lavras, MG, Brazil.

\subsection{Source of Plant Material Explants}

Mature fruits were collected from the AI33-CPAC access (Embrapa Cerrados), of the Germoplasm neem Bank of Embrapa Coastal Tablelands, pulped, and seeds washed with Twin. In a laminar flow chamber, seeds were disinfected according to Lédo et al. (2008): $70 \%$ alcohol wash for two minutes and then with $2 \%$ sodium hypochlorite for 20 minutes under stirring water, and thereafter three washes with autoclaved distilled water. After this procedure, seeds were inoculated into test tubes $(25 \mathrm{~mm} \times 150 \mathrm{~mm})$ containing $20 \mathrm{ml}$ of $1 / 2 \mathrm{MS}$ modified medium (Murashige \& Skoog, 1962), supplemented with 3\% sucrose, pH adjusted to 5.8, solidified with $0.6 \%$ agar and previously autoclaved. Cultures were maintained in a growth room at temperature of $26 \pm 2{ }^{\circ} \mathrm{C}$, relative humidity of about $70 \%$ and 16 -hour photoperiod with cold white light under $52 \mu \mathrm{mol} \mathrm{m}^{-2} \mathrm{~s}^{-1}$ of irradiance.

\subsection{Callus Induction}

For callus formation, 1-cm nodal segments were obtained from seedlings germinated in vitro after 60 days of cultivation. These were inoculated into sterile Petri dishes $(10 \mathrm{~mm} \times 15 \mathrm{~mm})$ containing $10 \mathrm{ml}$ of MS culture medium supplemented with $3 \%$ sucrose and combined with different 2,4-D (2,4-dichlorophenoxyacetic) and BAP (6-benzylaminopurine) concentrations for callus induction (Table 1), $\mathrm{pH}$ adjusted to 5.8, solidified with $0.5 \%$ agar and previously autoclaved. Cultures were maintained in a growth room in the dark at temperature of $26 \pm 2{ }^{\circ} \mathrm{C}$ and relative air humidity around $70 \%$. At 0 (mass of nodal segments without callus), 20, 40 and 60 days of culture, the percentage of callus formation was observed and the callus was weighed to obtain the mean mass of each treatment using a precision analytical scale. At the end of the 60 days of cultivation, the color and consistency of calli were evaluated through a scale of scores. For consistency: 1-semi-compact; 2-compact; 3friable. For color: 1-dark brown (oxidized); 2-light brown; 3-greenish; 4-yellowish; 5-white. 
Table 1. Culture medium composition for callus induction in Azadirachta indica A. Juss nodal segments

\begin{tabular}{lll}
\hline Tratament & $2,4-\mathrm{D}(\mathrm{mg} / \mathrm{l})$ & $\mathrm{BAP}(\mathrm{mg} / \mathrm{l})$ \\
\hline $\mathrm{T} 1$ & 1.0 & 0.0 \\
$\mathrm{~T} 2$ & 1.0 & 0.5 \\
$\mathrm{~T} 3$ & 1.0 & 1.0 \\
$\mathrm{~T} 4$ & 1.0 & 2.0 \\
\hline
\end{tabular}

\subsection{Histological Analysis}

\subsubsection{Optical Microscopy (OM)}

Histology was observed according to Castro (2009): five samples of the best callus treatment after 60 days were fixed in Formaldehyde-Alcohol 70\%-Glacial acetic acid solution (FAA) (Johansen, 1940). Dehydration was performed on an increasing ethylic series $(80 \%, 90 \%$, and 100\%) at intervals of 1 hour each. Then, samples were placed in a pre-infiltration solution for 2 hours and in an infiltration solution for 24 hours in refrigerator. Subsequently, the inclusion solution was prepared by adding hardener to the activated resin (following proportions indicated by historesin kit Leica Microsystems, Heidelberg, Germany). Plant fragments were infiltrated in histomolds and polymerized at room temperature. Having included the material, microtomy was performed using semi-automatic microtome. Setting thickness of $8 \mu \mathrm{m}$, cuts were made, and then they were extended on the blade, containing a small amount of water. After drying at room temperature, callus samples were stained with toluidine blue $\mathrm{pH} 4.8$ and then washed with acetic water. After drying, blades were fixed with glass varnish and later observed in an optical microscope (Nikon Eclipse E100 coupled with an Infinity 1 camera), in which photomicrographs were developed.

\subsubsection{Scanning Electron Microscopy (SEM)}

For observation of the callus surface, samples from the best treatment were fixed in Karnovsky (Karnovsky, $1965)$ solution until analysis. Samples were washed in $0.05 \mathrm{M}$ cacodylate buffer and post-fixed in $1 \%$ osmium tetroxide for $4 \mathrm{~h}$ at room temperature. Subsequently, they were dehydrated in a progressive acetone series $(25,50$, 75, 90 and 100\%), and critical point dried in CO2 in BAL-TEC, CPD-030 equipment, attached to a metallic support and coated with metallic gold $(10 \mathrm{~nm})$ in BAL-TEC, SCD-050 device. The prepared material was observed and electromicrographed with LEO EVO-40, PVX scanning electron microscope.

\subsection{Statistical Analysis}

The experiment was conducted in a completely randomized design using a plot subdivided in time, which is composed of 4 treatments (BAP concentrations) and subplot composed of 4 evaluation periods. Twelve replicates per treatment were used, each replicate being composed of one explant.

Statistical analysis of data was performed using the SAS-9.4 statistical software (SAS Institute, 2013). The comparison of the evaluation periods was done using the polynomial regression analysis and the Tukey test ( $\mathrm{p}<$ 0.05 ) was used for the BAP concentrations.

\section{Results}

\subsection{Callogenesis}

In all treatments, callus formation occurred, and the mass varied according to the time and BAP concentration in the culture medium. At time 0 , explants presented statistically the same mass. In the subsequent evaluation, at 20 days, callus formation was observed. For the 20- and 40-day evaluation periods, there was no difference in response among treatments. For 60 days, treatment T4 $(1.0 \mathrm{mg} / 1$ 2,4-D $+2.0 \mathrm{mg} / \mathrm{l} \mathrm{BAP})$ stood out, presenting $0.3343 \mathrm{~g}$ of callus mass (Table 2 ).

In treatment $1(1.0 \mathrm{mg} / 12,4-\mathrm{D})$ the greatest mass increment was obtained at 44 days On the other hand, in $\mathrm{T} 2$ $(1.0 \mathrm{mg} / 12,4-\mathrm{D}+0.5 \mathrm{mg} / 1 \mathrm{BAP})$, it occurred at 49 days, suggesting that from these times there is a need for a subculture to renew the nutrients and regulators of the culture medium and thus the new proliferation of cells in the respective treatments. For treatments 3 and 4 (1.0 mg/l 2,4-D + $1.0 \mathrm{mg} / \mathrm{l} \mathrm{BAP}$ and $1.0 \mathrm{mg} / \mathrm{l} 2,4-\mathrm{D}+2.0 \mathrm{mg} / 1$ BAP, respectively), the mass increment was linear (Figure 1). 
Table 2. Increase of neem callus mass (Azadirachta indica A. Juss), according to treatments and evaluation periods of cultivation

\begin{tabular}{|c|c|c|c|c|c|c|}
\hline \multirow{2}{*}{ Treatments } & \multicolumn{4}{|c|}{ Evaluation periods (days) } & \multirow{2}{*}{ - Equation } & \multirow{2}{*}{$\mathrm{R}^{2}$} \\
\hline & 0 & 20 & 40 & 60 & & \\
\hline $\mathrm{T} 1$ & $0.0137 \mathrm{a}$ & $0.1349 \mathrm{a}$ & $0.1418 \mathrm{a}$ & $0.1485 \mathrm{~b}$ & $y=-7 E-05 x^{2}+0.0064 x+0.0194$ & 94.7 \\
\hline $\mathrm{T} 2$ & $0.0169 \mathrm{a}$ & $0.1386 \mathrm{a}$ & $0.1526 \mathrm{a}$ & $0.1714 \mathrm{~b}$ & $y=-6 E-05 x^{2}+0.0062 x+0.0225$ & 95.7 \\
\hline $\mathrm{T} 3$ & $0.0093 \mathrm{a}$ & $0.0939 \mathrm{a}$ & $0.1336 \mathrm{a}$ & $0.1762 \mathrm{~b}$ & $\mathrm{y}=0.0027 \mathrm{x}+0.0222$ & 96.3 \\
\hline $\mathrm{T} 4$ & $0.0159 \mathrm{a}$ & $0.1361 \mathrm{a}$ & $0.2032 \mathrm{a}$ & $0.3343 \mathrm{a}$ & $\mathrm{y}=0.0051 \mathrm{x}+0.019$ & 98.6 \\
\hline CV1 $(\%)$ & 7.72 & & & & & \\
\hline CV2 $(\%)$ & 6.14 & & & & & \\
\hline
\end{tabular}

Note. Means followed by the same letter in the column do not differ from each other by the Tukey test $(p \leq 0.05)$.

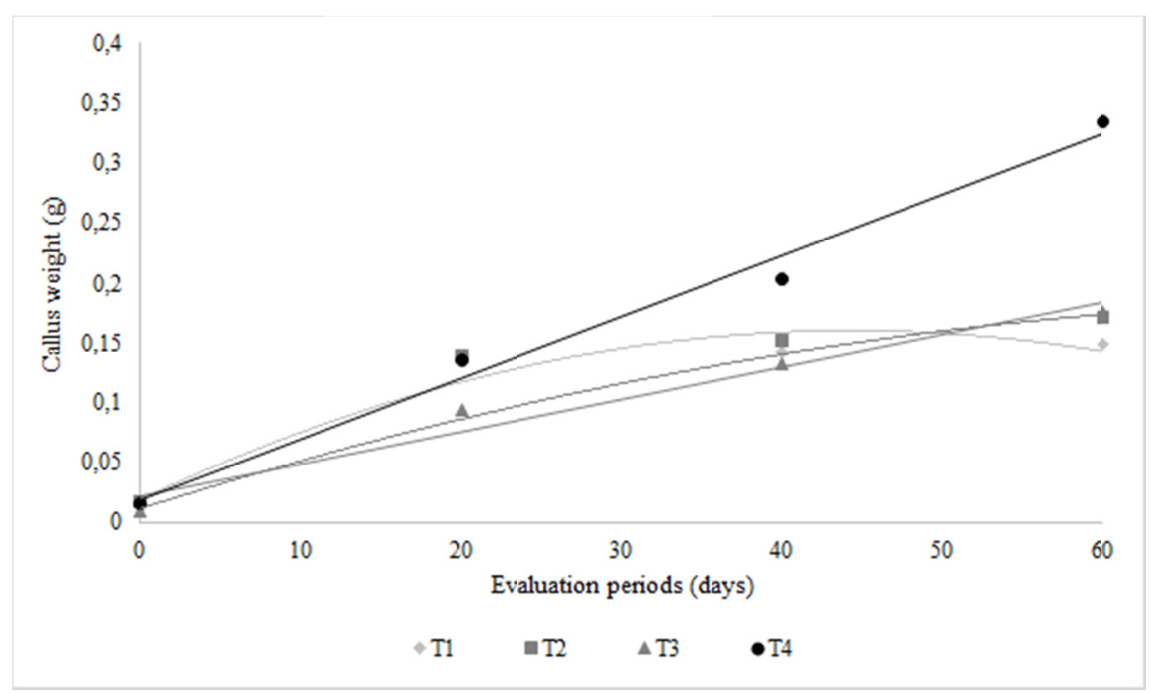

Figure 1. Neem callus mass (Azadirachta indica A. Juss), according to the cultivation time

\subsection{Histology}

All calli (100\%) formed from nodal Azadirachta indica segments showed light brown coloration and friable consistency (Figura 2A).

Through histological analysis, two types of cells were observed: round short cells, in higher amounts, and elongated cells. Cross sections have revealed that cell proliferation occurs from meristematic cells located in the central callus region. From the center to the callus periphery, an expansion zone was observed where outermost cells were more expanded, and many of these were isolated at the surface, but remaining united in the basal portion. The central callus region was compact with juxtaposed cells, with no intercellular spaces and with evidence of cell divisions (Figure 2B).

Nodal callus segment induced in culture medium with $1 \mathrm{mg} / 1$ 2,4-D $+2 \mathrm{mg} / \mathrm{l}$ BAP showed, for the most part, embryogenic callus aspects because they present short, round and isodiametric cells (Figure 2C), indicating mitotic potentiality.

A small number of cells presented elongated shape (Figure 2D). 

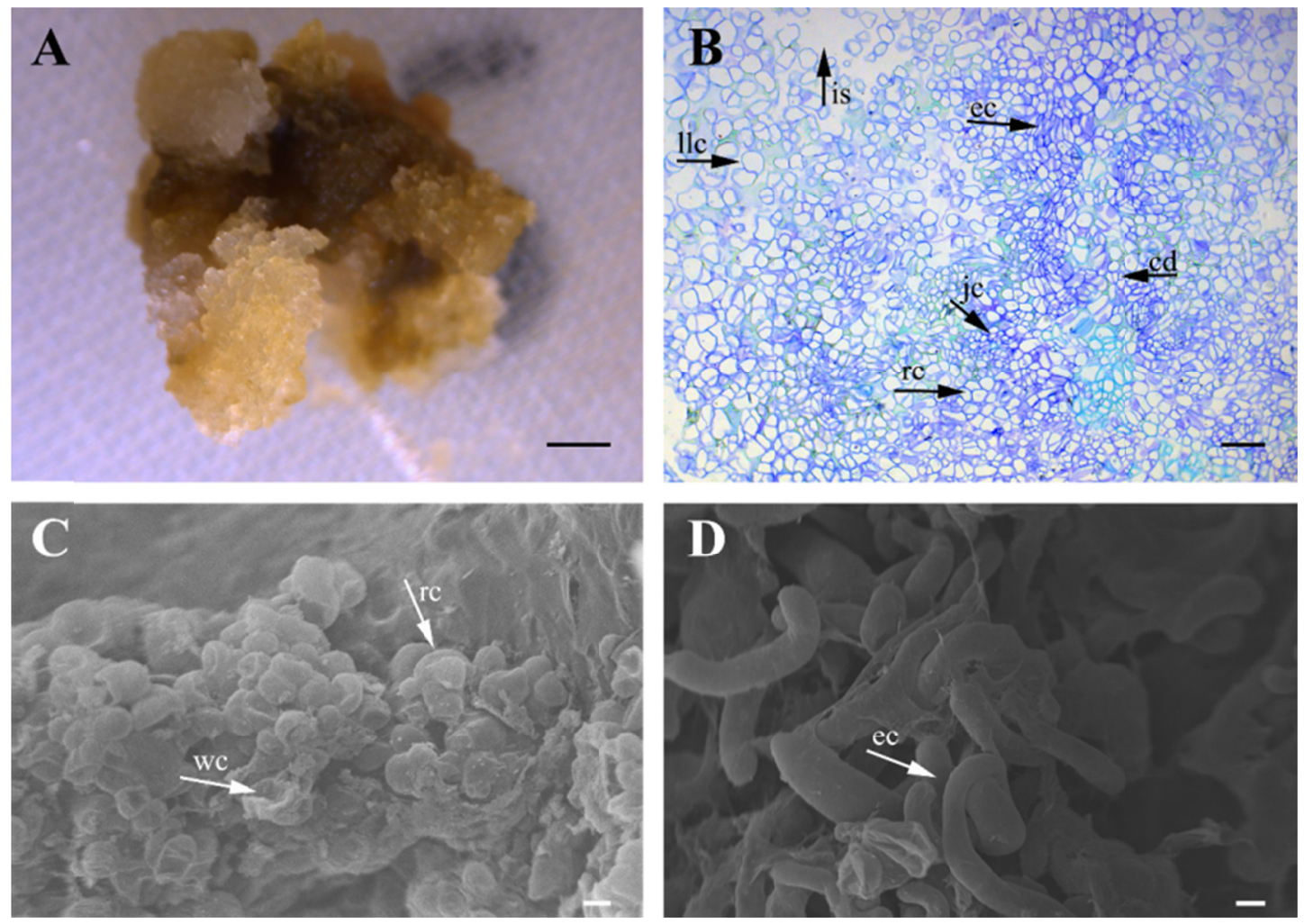

Figure 2. Histological sections of callus induction from nodal Azadirachta indica A. Juss explants at 60 days in treatment T4 (1mg/L de 2,4-D + 2 mg/L BAP). A: Friable callus with light brown coloration (Bar 3 mm); B: Optical photomicrograph of the cross-sectional section showing elongated cells (ec) and round cells (rc), central callus region formed by juxtaposed cells (jc) and evidence of cell division (cd), and peripheral region with large lumen cells (llc) and intercelular spaces (is) (Bar $100 \mu \mathrm{m}) ; \mathrm{C}$ and D: Scanning electron photomicrographs of callus showing round cells (rc), wilted cells (wc) and elongated cells (ec) (Bar $20 \mu \mathrm{m})$.

\section{Discussion}

\subsection{Callogenesis}

According to Azevedo (2003), identifying the stationary phase of mass increment is of extreme importance because it indicates the moment callus should be transferred to a new culture medium, avoiding the accumulation of toxic substances. In callus of "pequi tree" (Caryocar brasiliense Camb.), Landa et al. (2000), it was observed that the transfer to new culture medium should occur between the 46th and 49th days of culture.

The auxin-cytokinin balance determines the type of organ to be formed. Balanced concentrations of these two hormones result in the proliferation of undifferentiated callus. In callogenesis induction, the use of auxins is common. Auxins act to initiate cell division and control cell growth and elongation processes (Taiz \& Zeiger, 2009). In the present study, it was observed that callus formation occurred using auxin isolated and associated with cytokinin; however, the greatest mass increment occurred using the combination of regulators.

In Azadirachta indica, in vitro morphogenesis was induced from leaf and root explants grown in MS medium with $8.8 \mathrm{mM}$ BAP and $0.57 \mathrm{mM}$ AIA (indole 3-acetic acid) (Salvi et al., 2001). However, Rodrigues et al. (2009) observed that the highest callus formation in cotyledonary explants occurred in WPM medium containing 2.0 $\mathrm{mg} / \mathrm{l} \mathrm{BAP}$ and $2.0 \mathrm{mg} / 1$ 2,4-D. For callus induction, Singh and Chaturvedi (2013) used embryos cultured in MS medium supplemented with various combinations of regulators and detected that embryos in MS + BAP (5.0 $\mathrm{mM})+2.4-\mathrm{D}(1.0 \mathrm{mM})+$ ANA (1-naphthaleneacetic acid) $(1.0 \mathrm{mM})$ yielded $100 \%$ calogenesis. In the Azadirachta excelsa species, callus formation occurred in MS medium added of $19.6 \mu \mathrm{M}$ indolebutyric acid (AIB) and 4.4 $\mu \mathrm{M}$ BAP from leaf explants (Giagnacovo et al., 2001) (Giagnacovo et al., 2001).

In other studies with Meliaceae species such as "mogno" (Swietenia macrophylla King) epicotyl segments were inoculated in MS medium supplemented with combinations of BAP and ANA, and higher callus formation occurred in treatment composed of $1.0 \mathrm{mg} / \mathrm{l}$ and $0.25 \mathrm{mg} / \mathrm{l}$, respectively (Brunetta et al., 2006). Rocha and 
Quoirin (2004), also working with "mogno", observed that in leaf explants, $90 \%$ of them formed callus in culture medium containing $4.4 \mu \mathrm{M}$ BAP with $0.54 \mu \mathrm{M}$ ANA and $8.9 \mu \mathrm{M}$ BAP with 0.11 ANA or $0.54 \mu \mathrm{M}$.

These results show that there is variation among species of the same family, and also among genotypes of the same species, depending on the different growth conditions and composition of the culture medium (Rocha \& Quoirin, 2004).

\subsection{Histology}

Callus consistency is influenced by factors such as auxin, cytokinin, explant type and genotype (Navroski et al., 2012).

In order to obtain embryogenic cultures, it is indispensable the induction of friable callus by the presence of rounded cells with meristematic characteristics (Vasconcelos et al., 2012). Friable callus has the characteristic of disintegrating easily when manipulated. This friability is important for suspension cell cultures, since cells divide rapidly and disperse easily in the culture medium (Barrueto Cid, 1992).

The formation of the embryogenic callus precedes the formation of the somatic embryo. Dedifferentiation is the first step towards the acquisition of competence by the callus mass. Continuous cell divisions result in the formation of embryogenic cell masses that are characterized by being small, isodiametric, with little intercellular space and organized cell system, resembling meristematic cells. The division index of callus cells can elucidate the physiological changes of cells and aid in the optimization of regeneration protocols.

Callogenesis is an important process to obtain plants indirectly, because callus contains cells or a group of cells that have active centers of cell division. These centers, under appropriate conditions, are induced to specialize to produce organs (Rocha \& Quoirin, 2004).

Short, round and isodiametric cells coincide with those observed by several authors that define them as a common occurrence in viable cells of embryogenic calli. Padua et al. (2014) also detected isodiametric cells with evident nucleus in friable Coffea arabica callus.

Cellular elongation is characteristic of non-viable cells for somatic embryogenesis (Nogueira et al., 2007). Thus, the cellular structure of callus induced from nodal $A$. indica explants may indicate that the elongated cells observed are not viable for somatic embryogenesis but may be efficient for studies on the storage of secondary metabolites.

In studies on the surface analysis of callus obtained from "aroeira-do-sertão" leaf segments (Myracrodruon urundeuva Fr. All.), there were non-granular, compact structures and non-embryogenic characteristics (Vasconcelos et al., 2012). Nogueira et al. (2007) observed that the cells of "murici-pequeno" callus (Byrsonima intermedia A. Juss.) induced from leaf segments inoculated in MS culture medium supplemented with $1.0 \mathrm{mg} / 1$ of 2.4-D, altered the elongated to an isodiametric format and presented subcellular structures that characterize meristematic cells with embryogenic capacity. Ribeiro et al. (2012) working with callus obtained from "banana prata-anã" (Musa sp.) leaf explants identified that Type-1 callus (transparent and aqueous callus) cells were elongated and that Type-2 and Type-3 callus cells (yellow callus with small clusters and large clusters, respectively), were isodiametric, which is a characteristic of embryogenic cells. Chiavegatto et al. (2015) working with "murici-cascudo" (Byrsonima verbascifolia) observed that callus with 20 and 30 days showed embryogenic cells, that is, isodiametric, juxtaposed with small vacuoles and that after 120 days, calli were mainly formed by elongated cells with lower viability and mitotic index.

\section{Conclusions}

The highest induction of Azadirachta indica A. Juss callus was observed in the presence of $1.0 \mathrm{mg} / 12,4-\mathrm{D}+2.0$ $\mathrm{mg} / \mathrm{l} \mathrm{BAP}$, with callus showing light brown coloration, friable consistency and rounded cells with intense cell division, typical of cells with potential embryogenic capacity.

\section{References}

Akula, C., Akula, A., \& Drew, R. (2003). Somatic embryogenesis in clonal nem, Azadirachta indica A. Juss. and analysis for in vitro azadirachtin production. In vitro Cellular e Developmental Biology-Plant, 39, $304-310$. https://doi.org/10.1079/IVP2003415

Azevedo, K. S. (2003). Indução e análises bioquímicas de calos e aspectos de anatomia foliar de Copaíba (Copaifera langsdorffii Desf.) (Master's thesis, Universidade Federal de Lavras, Minas Gerais, Brazil).

Barrek, S., Paisse, O., \& Grenier-Loustalot, M. F. (2004). Analysis of neem oil by LC-EM and degradation kinetics of azadirachtin-A in a controlled environment. Characterization of degradation products by 
HPLC-MS/MS. Analytical and Bioanalytical Chemistry, 378, 753-763. https://doi.org/10.1007/s00216-0032377-0

Barrueto Cid, L. P. B. (1992). A cultura de células vegetais em meio líquido. ABCTP Notícias, 18, 02-07.

Bleicher, E., Gonçalves, M., \& Silva, L. (2007). Efeito de derivados de nim aplicados por pulverização sobre a mosca-branca em meloeiro. Horticultura Brasileira, 25, 110-113. https://doi.org/10.1590/S0102-05362 007000100022

Brunetta, J. M. F. C., Otoni, W. C., Pinheiro, A. L., \& Fonseca, E. P. (2006). Calogênese in vitro em segmentos de epicótilo de mogno (Swietenia macrophylla King) com uso de 6- benzilaminopurina e ácido-naftalenoacético. Scientia Forestalis, 71, 19-24.

Castro, E. M., Pereira, F. J., \& Paiva, R. (2009). Histologia vegetal: estrutura e função de órgãos vegetativos. Lavras: UFLA.

Chiavegatto, R. B., Castro, A. H. F., Marçal, M. G., Pádua, M. S., Alves, E., \& Techio, V. H. (2015). Cell Viability, Mitotic Index and Callus Morphology of Byrsonima verbascifolia (Malpighiaceae). Tropical Plant Biology, 8 , 87-97. https://doi.org/10.1007/s12042-015-9150-3

Elhiti, M., \& Stasolla, C. (2001). The use of zygotic embryos as explants for in vitro propagation: An overview. In T. A. Thorpe, \& E. C. Yeung (Eds.), Plant embryo culture: Methods and protocols (pp. 229-255). New York: Humana.

Giagnacovo, G., Pasqua, G., Monacelli, B., Van, S. A., Maccioni, O., \& Vitali, F. (2001). Organogenesis and embryogenesis from callus cultures of Azadirachta excelsa. Plant-Biosystems, 135, 13-18. https://doi.org/ $10.1080 / 11263500112331350590$

Johansen, D. A. (1940). Plant microtechnique. New York: McGraw-Hill Book.

Karnovsky, M. J. (1965). A formaldehyde-glutaraldehyde fixative of high osmolality for use in eletron microscopy. Journal of Cellular Biology, 27, 137-138.

Landa, F. S. L., Paiva, R., Paiva, P. D. O., \& Bueno Filho, J. S. S. (2000). Indução in vitro de calos em explantes foliares de pequizeiro (Caryocar brasiliense Camb.). Ciência e Agrotecnologia, 24, 56-63.

Lédo, A. S., Blank, A. F., Barboza, S. B. S. C., Rangel, M. S. A., \& Lédo, C. A. S. (2008). Germinação in vitro de embriões zigóticos e sementes de nim indiano (Azadirachta indica A. Juss.). Revista Brasileira de Plantas Medicinais, 10, 1-5.

Lekshmi, P. N. C. J., Sowmia, N., Viveka, S., Brindha, R. J., \& Jeeva, S. (2012). The inhibiting effect of Azadirachta indica against dental pathogens. Asian Journal of Plant Science and Research, 2, 6-10.

Mohapatra, B. B., Das, M. C., Dinda, S. C., \& Nagoji, K. E. V. (2012). Anti-ulcer activity of aqueous and ethanolic leaf extract of neem (Azadirachta indica) in albino rats. Journal of Pharmacy Research, $5,1571$.

Murashige, T., \& Skoog, F. A. (1962). A revised medium for rapid growth and bioassays with tobacco tissue cultures. Physiologia Plantarum, 15, 473-497. https://doi.org/10.1111/j.1399-3054.1962.tb08052.x

Nahak, G., \& Sahu, R. K. (2011). Evaluation of antioxidant activity of flower and seed oil of Azadirachta indica A. Juss. Journal of Applied and Natural Science, 3, 78-81. https://doi.org/10.31018/jans.v3i1.158

Navroski, M. C., Waldow, D. A. G., Pereira, M. O., \& Pereira, A. O. (2012). Calogênese in vitro de segmentos apicais caulinares e internodais em segurelha (Satureja hortensis L.). Revista Agro@mbiente On-line, 6, 228-234. https://doi.org/10.18227/1982-8470ragro.v6i3.698

Neves, B. P., Oliveira, I. P., \& Nogueira, J. C. M. (2003). Cultivo e Utilização do Nim indiano. Circular Técnica Embrapa, Goiás.

Nogueira, R. C., Paiva, R., Oliveira, L. M., Soares, G. A., Soares, F. P., Castro, A. H. F., \& Paiva, P. D. O. (2007). Indução de calos em explantes foliares de Murici-pequeno (Byrsonima intermedia A. Juss.). Ciencia e Agrotecnologia, 31(2), 366-370. https://doi.org/10.1590/S1413-70542007000200015

Oliveira, R. P., Raseira, M. C. B., \& Nickel, O. (2015). Produção de mudas certificadas de framboeseira por meio de cultura in vitro de tecidos (p. 49). Pelotas: Embrapa Clima Temperado.

Ozias-Akins, P., \& Vasil, I. K. (1985). Nutrition of plant tissue cultures. In I. K. Vasil (Ed.), Cell culture and somatic cell genetics of plants: Cell growth, nutrition, cytodifferenciation and cryopreservation (Vol. 2, pp. 128-147). Florida: Academic. 
Padua, M. S., Paiva, L. V., Silva, L. C., Livramento, K. G., Alves, E., \& Castro, A. H. F (2014). Morphological characteristics and cell viability of coffee plants calli. Ciência Rural, 44, 660-665. https://doi.org/ 10.1590/S0103-84782014000400014

Patil, P., Patil, S., Mane, A., \& Verma, S. (2013). Antidiabetic activity of alcoholic extract of Neem (Azadirachta indica) root bark. National Journal of Physiology, Pharmacy \& Pharmacology, 3, 142-146. https://doi.org/ 10.5455/njppp.2013.3.134-138

Redbio Martinez, S. S. (2008). O nim-Azadirachta indica-um inseticida natural. Londrina: IAPAR.

Ribeiro, L. O, Paiva, L. V., Pádua, M. S., Santos, B. R., Alves, E., \& Stein, V. C. (2012). Morphological and ultrastructural analysis of various types of banana callus, cv. Prata anã. Acta Scientiarum Agronomy, 34, 423-429. https://doi.org/10.4025/actasciagron.v34i4.14501

Rocha, S. C., \& Quoirin, M. (2004). Calogênese e rizogênese em explantes de mogno (Swietenia macrophylla King) cultivados in vitro. Ciência Florestal, 14, 91-101. https://doi.org/10.5902/198050981785

Rogrigues, M., Paiva, R., Nogueira, R. C., Martinotto, C., \& Silva Junior, J. M. (2009). Morfogênese in vitro de nim a partir de explantes cotiledonares. Revista Árvore, 33, 21-26. https://doi.org/10.1590/S0100-67622 009000100003

Salvi, D. N., Singh, H., Tivarekar, S., \& Eapen, S. (2001). Plant regeneration from different explants of neem. Plant Cell Tissue and Organ Culture, 65, 159-162. https://doi.org/10.1023/A:1010672809141

SAS Institute Inc. (2013). Statistical Analysis System, SAS 9.4 Help and Documentation. Cary, NC: SAS Institute Inc. Retrieved http://www.sas.com/en_us/software/sas9.html

Sidhu, O. P., Kumar, V., \& Behl, H. M. (2003). Variability in neem (Azadirachta indica) with respect to azadirachtin content. Journal of Agricultural and Food Chemistry, 51, 910-915. https://doi.org/10.1021/ jf025994m

Singh, M., \& Chaturvedi, R. (2013). Sustainable production of azadirachtin from differentiated in vitro cell lines of neem (Azadirachta indica). AoB Plants, 5. https://doi.org/10.1093/aobpla/plt034

Vasconcelos, J. N. C., Cardoso, N. S. N., Oliveira, L. M., Santana, J. R. F., Fernandez, L. G., Bello Koblitz, M. G., \& Silva, M. L. C. (2012). Indução, caracterização bioquímica e ultra-estrutural de calos de aroeira-do-sertão (Myracrodruon urundeuva Fr. All.). Revista Brasilera Plantas Medicinais, 14, $592-597$. https://doi.org/10.1590/S1516-05722012000400004

Venkateswarlu, B., \& Mukhopadhyay, K. (1999). Azadirachtin content in the seeds of micropropagated neem plants in relation to its mother tree. Current Science, 76, 626-627.

\section{Copyrights}

Copyright for this article is retained by the author(s), with first publication rights granted to the journal.

This is an open-access article distributed under the terms and conditions of the Creative Commons Attribution license (http://creativecommons.org/licenses/by/4.0/). 